\title{
U-Pb GEOCHRONOLOGY OF GNEISSES AND GRANITOIDS IN THE QUADRILÁTERO FERRÍFERO (SOUTHERN SÃO FRANCISCO CRATON): AGE CONSTRAINTS FOR ARCHEAN AND PALEOPROTEROZOIC MAGMATISM AND METAMORPHISM
}

\author{
CARLOS MAURÍCIO NOCE*, NUNO MACHADO** AND WILSON TEIXEIRA****
}

\begin{abstract}
RESUMO GEOCHRONOLOGIA U-Pb DE GNAISSES E GRANITÓ1DES DO OUADRILÁTERO FERRÍFERO \{CRATON DO SÃO FRANCISCO MERIDIONAL) : IDADE DO MAGMATISMO E METAMORFISMO ARQUEANO E PALEOPROTEROZÔICO Determinações U-Pb foram realizadas em gnaisses e granitóides do Quadrilátero Ferrífero, porção sul do Craton do São Francisco. O Complexo Belo Horizonte representa um segmento de crosta arqueana, composto principalmente por gnaisses bandados do tipo TTG, afetados por migmatização. Este evento de migmatização foi datado em 2860+14/-10 Ma. Plutons graníticos, de derivação crustal, são intrusivos nos gnaisses e um deles apresenta idade U-Pb em zircão de 2712+5/-4 Ma. A intrusão de um pequeno corpo granítico, datada em 2612+37-2 Ma, marca o último evento magmático arqueano registrado no Quadrilátero Ferrífero. O conjunto de determinações geocronológicas disponíveis para o Quadrilátero Ferrífero permite estabelecer um quadro evolutivo para a crosta arqueana. O principal período de geração crustal ocorreu entre 3,0-2,9 Ga, conforme sugerido pela assinatura isotópica do $\mathrm{Nd}$ para os gnaisses TTG. Após este período, a progressiva amalgamação de blocos continentais ocasionou intenso retrabalhamento da crosta primitiva, associado a diversos episódios de granitogênese e a deposição de seqüência do tipo greenstone belt. Uma extensa área cratônica foi consolidada após $2,6 \mathrm{Ga}$, sendo recoberta por sedimentos plataformais. A intrusão do Tonalito Alto Maranhão ocorreu em 2124 \pm 1 Ma. Este corpo possui assinatura isotópica juvenil e associa-se à Orogênese Transamazônica. Titanita do gnaisse TTG e leucossoma alinham-se em uma discórdia, com intercepto inferior em 2041 $\pm 5 \mathrm{Ma}$, definindo o pico metamórfico deste evento.
\end{abstract}

Palavras-chaves:

ABSTRACT U-Pb analyses were carried out on gneisses and granitoids from the Quadrilátero Ferrífero area, in the southern São Francisco craton. The Belo Horizonte complex represents a segment of Archaean crust principally composed of migmatized banded TTG-type gneisses. Migmatization event took place at 2860+14/-10 Ma. Granitic plutons intruded in the complex are crust-derived and one of them yielded a zircon age of 2712+5/-4 Ma. The emplacement of a small granitic pluton at $2612+37-2$ Ma defines the youngest Archaean magmatic event in the Quadrilátero Ferrífero. This set of geochronological determinations together with published data allows the establishment of a fairly accurate framework for the evolution of the Archaean crust in the Quadrilátero Ferrífero. The main period of crust generation at 3.0 to $2.9 \mathrm{Ga}$ is indicated by Nd isotopic signature of TTG gneisses. The evolutionary trend followed the progressive amalgamation of continental blocks, associated with intensive reworking of the primitive crust, renewed events of granitoid emplacement and greenstone belt deposition. An extensive cratonic area consolidated at $c a .2 .6 \mathrm{Ga}$ and was subsequently covered by stable-shelf sediments. The Alto Maranhão pluton was emplaced at $2124 \pm 1 \mathrm{Ma}$. This tonalitic intrusion represents an isotopically juvenile body related to the Transamazonian Orogeny. Titanite of the TTG-gneiss and leucosome align in a discordia with a lower intercept at $2041 \pm 5$ Ma defining the metamorphic peak of this event.

Keywords:

INTRODUCTION The Quadrilátero Ferrífero (Iron Quadrangle) is a $c a$. $7000 \mathrm{~km}^{2}$ area in the southern São Francisco craton in Brazil, comprising a Neoarchean greenstone belt surrounded by older gneiss complexes and overlain by a Paleoproterozoic sedimentary succession, all of them affected by the $c a$. 2.0 Ga Transamazonian Orogeny. The Quadrilátero Ferrífero provides an opportunity to investigate several aspects of crustal evolution, from greenstone beltgneiss terrain relationships to Paleoproterozoic basin formation and orogenesis. In this paper we report the ages of important gneiss and granitoid units and consider their significance in the evolution of the area.

Precise U-Pb dating of zircon, titanite and monazite disclosed new magmatic and metamorphic events in the Quadrilátero Ferrífero. A large set of geochronological determinations is now available for this area. Therefore, a chronology of geologic events has been established as discussed hereafter.

GEOLOGICAL SETTING AND PREVIOUS GEOCHRONOLOGY Archean terranes of the Quadrilátero
Ferrífero comprise a granite-greenstone belt association surrounded by granite-gneiss complexes (Fig. 1)..The former is included in the Rio das Velhas Supergroup (Dorr etal. 1957), the basal unit of which (Nova Lima Group) consists of a volcano-sedimentary sequence hosting the main gold deposits of the Quadrilátero Ferrífero. Two felsic volcanic rocks of the Nova Lima Group have been dated at $2772 \pm 6 \mathrm{Ma}$ and $2776+237-10 \mathrm{Ma}$ (U-Pb data in Machado et al 1992). Tpnalitic-granodioritic intrusions associated with the formation of the greenstone belt yielded U-Pb ages of 2776+77-6 Ma and 2780+37-2 Ma (Caeté and Samambaia intrusions; Machado et ai. 1992; Machado \& Carneiro 1992). These syn-volcanic intrusions occur at the margins of the greenstone belt and are partially or totally emplaced into the granite-gneiss complexes surrounding the greenstone belt.

The granite-gneiss terranes comprise several complexes (Herz 1970): Belo Horizonte to the north of Quadrilátero Ferrífero, Caeté to the northeast, Bação in the center, and Bonfim to the west (Fig. 1). The northern sector of the Bonfim complex is well known in geological detail supported by $\mathrm{U}-\mathrm{Pb}$ data. The main unit is a banded gneiss, locally migmatized

* Centro de Pesquisa Prof. Manuel Teixeira da Costa, Instituto de Geociências, Universidade Federal de Minas Gerais, Av. Antônio Carlos 6627, $31270-901$ Belo Horizonte (MG), Brazil, e-mail: noce@dedalus.lcc.ufmg.br

** GEOTOP-Sc. de Ia Terre, Université du Quebec à Montreal, CP 8888, Succ. Centre-Ville, Montreal, Qc H3C 3P8 Canada

*** Instituto de Geociências, Universidade de São Paulo, CP 11348,05422-970 São Paulo (SP), Brazil 
(Carneiro 1992). The gneiss has a minimum age of $2920 \mathrm{Ma}$ and underwent remobilization during greenstone belt formation at $2772 \pm 6 \mathrm{Ma}$ and tonalitic intrusion at $2780+3 /-2 \mathrm{Ma}$ (Machado \& Carneiro 1992). 2703+24/-23 Ma granitic dykes crosscutting the regional foliation (Machado \& Carneiro 1992) represents the youngest Archaean event recorded in the Bonfim Complex.

The Transamazonian Orogeny (ca. 2.0 Ga) resulted in remobilization in the $\mathrm{B}$ ação Complex as shown by U-Pb ages of $2059 \pm 6 \mathrm{Ma}$ and $c a .2030 \mathrm{Ma}$ for titanitc and monazite from an amphibolite and an undeformed pegmatite (Machado etal. 1992).

The Proterozoic Minas Supergroup tectonically overlies the Archaean units (Fig. 1) and comprises the Caraça, Itabira, and Piracicaba groups (Dorr 1969). The Caraça Group is composed predominantly of quartzites and phyllites. The Caue Formation, at the base of the Itabira Group, comprises mainly Lake Superior-type banded iron formation, whilst the Gandarela Formation, at the top of the group, is composed of dolomitic carbonates with stromatolites, and was probably deposited at $2420 \pm 19 \mathrm{Ma}(\mathrm{Pb}-\mathrm{Pb}$ whole-rock isochron; Babinski etal. 1995). Interbedded quartzite and phyllite containing carbonatic lenses characterize the Piracicaba Group. Its upper unit (Sabará Formation) is composed of chlorite schists, phylites, graywackes, conglomerates, quartzites, and rare iron formation. The maximum age for the deposition of the Sahara Formation is $2125 \pm 4 \mathrm{Ma}$, the age of detrital zircon from a graywacke (Machado etal. 1992).

STUDY AREA The Belo Horizonte granitegneiss complex The Belo Horizonte complex is located to the north of the Quadrilátero Fern'fero (Fig. 1). The dominant rock type is a migmatitic banded gneiss with schlicren and stromatic structures and mafic enclaves, and is hereafter referred to as the Belo Horizonte gneiss. The foliation varies from N-S to NNE-WSE, dips $40-60^{\circ}$ to $\mathrm{W}$ and WNW, and is broadly coeval with migmatization as indicated by leucosomes both parallel and secant to the regional foliation. Nebulitic leucosomes may also preserve relicts of the foliation. Some locations display a transposed older foliation.

Chemical analyses of the least migmatized gneisses yielded a predominantly trondhjemitic composition (Noce et al. 1997). Biotite is the main mafic mineral (up to 5-10\%) whilst hornblende is rare. Most rocks display granoblastic or mylonitic textures.

The Belo Horizonte gneiss was intruded by granitoids ranging from pegmatitic veins to large bodies that can be divided into foliated and weakly or non foliated types. The former comprises the Santa Luzia and General Carneiro plutons (Fig. 1), which are generally homogeneous, post-date migmatization, and consists of calc-alkaline and slightly peraluminous granites. The Morro da Pedra and Córrego do Brumado (Fig. 1) are smaller peraluminous granite intrusions slightly foliated. The former is the only intrusive body known to intersect the Minas Supergroup. It is a $400 \mathrm{mx} 700 \mathrm{~m}$ intrusion outcropping within the Sabará Formation and considered intrusive, although contacts are not exposed (Pomerene 1964).

\section{Granitoids of the southern Quadrilátero Fern'fero}

In the southern Quadrilátero Fern'fero, the Minas Supergroup is separated from the other units by the Engenho and Moeda faults (Fig. 1). To the west of the latter occurs a gneiss complex composed of banded migmatitic gneisses similar to those of the Bonfim and Belo Horizonte complexes. A small granitic pluton (Salto do Paraopeba granite, Fig. 1) is intrusive into the gneisses and is partially overlain by the Moeda Formation of the Minas Supergroup. The Salto do Paraopeba granite is leucocratic and composed of quartz, microcline, oligoclase, and minor biotite. It is weakly deformed except for narrow shear zones that display strong grain comminution. Close to the contact between the granite and the supracrustal rocks, four tabular pegmatites are intruded into the quartzite layering. The pegmatites are $10-50 \mathrm{~cm}$ wide, pervasively kaolinized, foliated and boudinaged.

South of the Engenho fault, the greenstone sequences of the Nova Lima Group were intruded by the Alto Maranhão pluton (Fig. 1, Sad et al. 1983). This tonalitic intrusion is generally well foliated. The main components are oligoclase, quartz, biotite, and amphibole in a granoblastic texture. It is mctaluminous and can be classified as I type according to the scheme of Chapell \& White (1974).

GEOCHRONOLOGY Analytical methods U-Pb measurements were performed in the Centre de Recherche en Gcochimie Isotopique et en Géochronologie (GEOTOP) of the Université du Quebec à Montreal. Crystal selection, chemistry, mass spectrometry, and data treatment broadly followed previously described procedures (Davis 1982, Krogh 1973, 1982, Machado et al. 1996a). For zircon analyses, blanks are below $10 \mathrm{pg} \mathrm{Pb}$ and $2 \mathrm{pg}$ U. For titanite and monazite, maximum blanks are $15 \mathrm{pg} \mathrm{Pb}$ and $5 \mathrm{pg} \mathrm{U}$. The highest analytical uncertainty of the two $\mathrm{Pb} / \mathrm{U}$ ratios was used for error representation in figures 2 and 3 . The uncertainty in $\mathrm{Pb} / \mathrm{Pb}$ was calculated with an error propagation routine which takes into consideration the analytical precision of the measured isotopic ratios. The isotopic composition of initial common $\mathrm{Pb}$ was calculated using the model of Stacey \& Kramers (1975). Uncertainties are listed (Table 1) and represented (Figs. 2 and 3 ) at the 1 sigma level. Ages are quoted at the $95 \%$ confidence interval.

Results BELO HORIZONTE COMPLEX Two samples of the Belo Horizonte gneiss (N-33A, N-33B) were collected for $\mathrm{U}-\mathrm{Pb}$ geochronology. Sample 33A is representative of the migmatitic gneiss with thin leucosome layers, and 33B is from a $0.5 \mathrm{~m}$ wide felsic leucosome occurring in the axial plane of a tight fold. Zircons from the first sample were too small and altered to yield reliable results and were not analyzed. The leucosome yielded a small amount of zircon of high magnetic susceptibility and pervasive white alteration precluding a rigorous typological examination. The least altered zircon type consists of pink euhedral 3:1 prisms devoid of obvious cores. In order to remove or weaken the altered portions, a selection of crystals of this type was submitted to HF attack, monitored under a binocular microscope, and subsequently abraded. One of the three zircon fractions treated that way is concordant at $2860 \pm 17 \mathrm{Ma}$ (33B-3J whilstthe other two are $11 \%$ discordant and yield similar ${ }^{207} \mathrm{~Pb} /{ }^{206} \mathrm{~Pb}$ ages of 2823 $\mathrm{Ma}$ and $2813 \mathrm{Ma}$ (33B-1 and 33B-2). The three analyses define a discórdia line (23\% probability of fit) with the upper intercept at 2860+147-10 Ma (Table 1, Fig. 2a). The only zircon recovered from the least magnetic fractions is distinctly reddish, lower in U contents (75ppm vs.103-165 ppm for the previous zircons) and yielded a ${ }^{207} \mathrm{~Pb} /{ }^{206} \mathrm{~Pb}$ minimum age of

$2923 \mathrm{Ma}(2.3 \%$ discordant, analysis 33B-4). This is interpreted as an inherited zircon from the gneiss. Both rocks contain dark brown titanite; the one from the leucosome being concordant at $2041 \pm 5 \mathrm{Ma}$ (33B-5) whilst two abraded titanite fractions from the gneiss are 4-6\% discordant and yielded minimum ages of $2312 \mathrm{Ma}$ and $2227 \mathrm{Ma}$ (33A-1 and 33A-2, Table 1, Fig. 2a). The three titanite analyses define a discórdia with an upper intercept at $2847+81 /-77 \mathrm{Ma}$, similar to the zircon age for the leucosome $(2860+14 /-10 \mathrm{Ma})$. It can be concluded that migmatization occurred at $2860 \mathrm{Ma}$ forming zircon and titanite. During the Transamazonian Orogeny titanite in the leucosome was completely reset at $2041 \mathrm{Ma}$ whilst titanite in the gneiss was partially reset. 


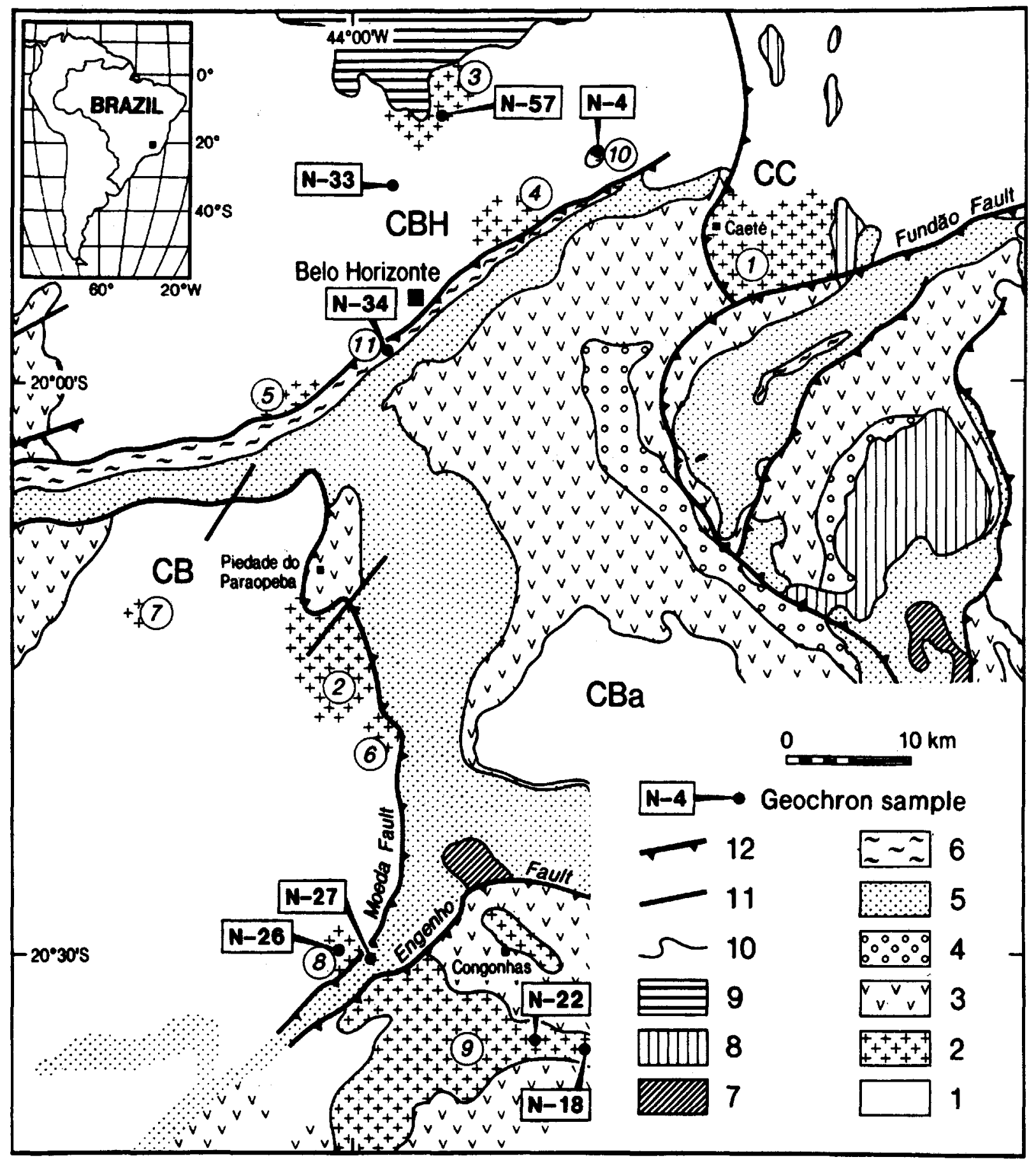
(1) Caeté granodiorite
(4) General Carneiro
(7) Brumadinho
(2) Samambaia
(5) Ibirite
(8) Salto do Paraopeba
(3) Santa Luzia
(6) Mamona
(9) Alto Maranhăo
(10) Corrego do Brumado

Figure 1 - Geology of the Quadrilatero Ferrifero (modifiedfrom Dorr 1969). Granitoid bodies are numbered at the figure bottom. Sample numbers are displayed inside rectangles. Legend: $1=$ granite-gneiss complexes $(C B H=B e l o$ Horizonte complex; $C C=$ Caeté complex; $C B a=$ Bação complex; $B C=$ Bonfim complex); $2=$ Archaean and Paleoproterozoic granitoid bodies. Rio das Velhas Supergroup: 3 = Nova Lima Group; 4 = Maquine Group. Minas Supergroup: 5 - Caraça, Itabira and lower Piracicaba groups; 6 = Sahara Formation. 7 = Itacolomi Group. Meso and Neoproterozoic units: 8 - Espinhaço Group; 9 = Bambui Group. $10=$ geologic contact; $11=$ vertical or undetermined faults; $12=$ thrust faults.

Figura 1 - Geologia do Quadrilátero Ferrífero (modificado de Dorr 1969). Corpos de granitóides estão numerados ao pé da figura. Números das amostras estão localizados no interior dos retângulos. Legenda: $1=$ complexos granito-gnáissicos $(\mathrm{CBH}=$ Complexo Delo Horizonte; $\mathrm{CC}=\mathrm{Complexo}$ Caeté; $\mathrm{CBa}=\mathrm{Complexo}$ Bação; BC = Complexo Bonfim); 2 = granitóides arqueanos e paleoproterozóicos. Supergrupo Rio das Velhas: 3 = Grupo Nova Lima; 4 = Grupo Maquine. Supergrupo Minas: 5 = grupos Caraça, Itabira e Piracicaba Inferior; 6 = Formação Sabará. 7 = Grupo Itacolomi. Unidades meso e neoproterozóicas: $8=$ Grupo Espinhaço; 9 = Grupo Bambuí. 10 = contato geológico; 11 = falhas verticais ou indeterminadas; 12 = falhas de empurrão. 
The same sample of the leucosome layer (33B) together with another sample of the migmatitic gneiss (331) were analyzed by the Sm-Nd method (Noce 1995). £Nd values for $\mathrm{t}=2.86 \mathrm{Ga}$ are slightly negative $(-1.2$ and -1.6$)$ suggesting that the protholiths are not significantly older than the inherited zircon minimum age of $2922 \mathrm{Ma}$. This is in agreement with the gneiss Sm-Nd model age (TDM) of $2.97 \mathrm{Ga}$.

The Santa Luzia granite (N-57) yielded pink, euhedral and small zircon prisms and fragments with variable amounts of white alteration. The relatively small grain size precluded long abrasion times. Three analyses (57-1, 57-2 and 57-3) are
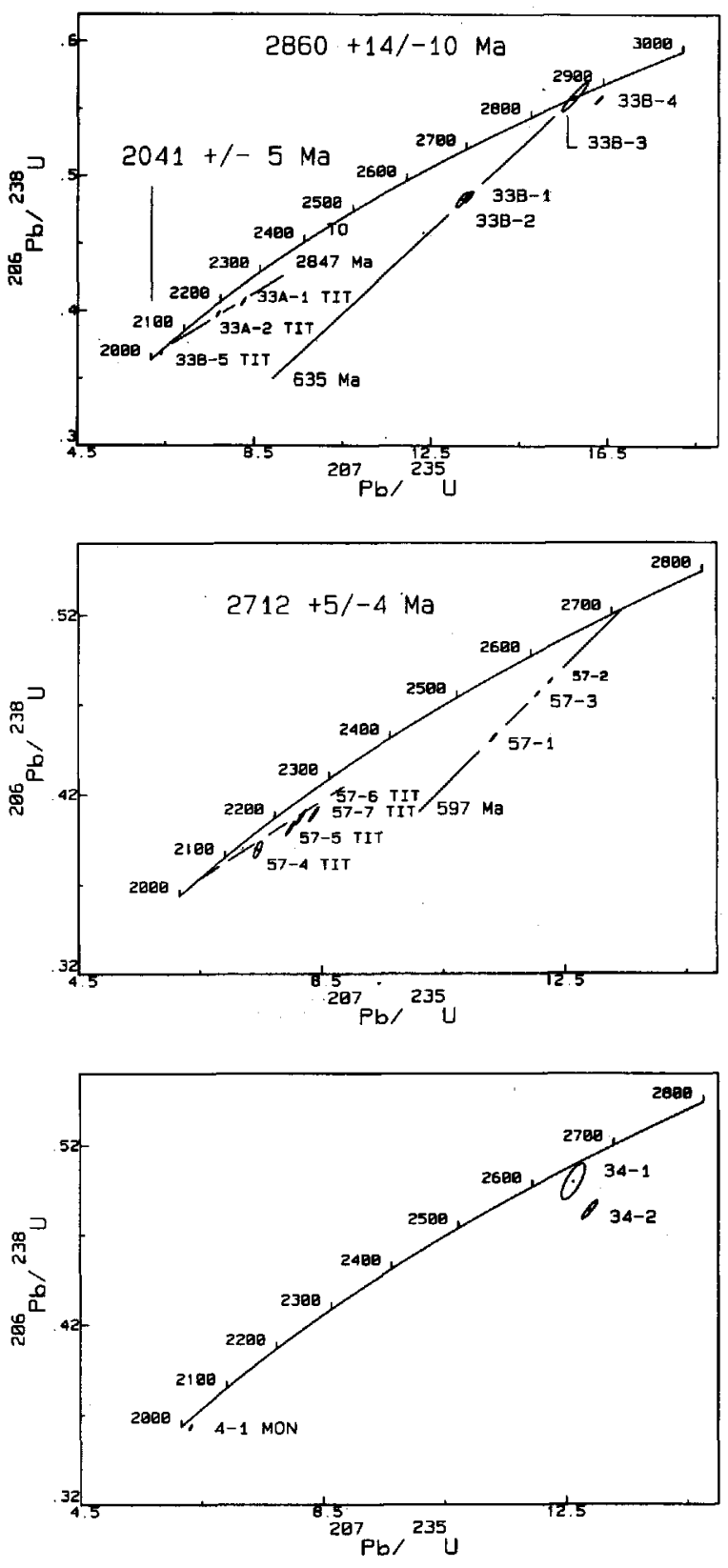

Figure 2 - (a) concórdia diagram for a migmatitic gneiss (sample 33A) and a leucossome (sample 33B) from the Belo Horizonte complex, (b) concórdia diagram for the Santa Luzia granite, (c) concórdia diagram for the Morro da Pedra granite (sample 34) and Córrego Brumado granite (sample 4). Figura 2 - (a) diagrama concórdia de um gnaisse migmatítico (amostra 33A) e um leucossoma (amostra 33B) do Complexo Belo Horizonte, (b) diagrama concórdia do Granito Santa Luzia, (c) diagrama concórdia do Granito Morro da Pedra (amostra 34) e do Granito Córrego Brumado (amostra 4). between $9 \%$ and $17 \%$ discordant and define a discórdia $(56 \%$ probability of fit) with the upper intercept at $2712+5 /-4$ Ma (Table 1, Fig. 2b) taken as the age of crystallization of the granite. Four fractions of titanite which underwent variable abrasion times are discordant with ${ }^{207} \mathrm{~Pb} /{ }^{206} \mathrm{~Pb}$ ages between $2328 \mathrm{Ma}$ and $2212 \mathrm{Ma}$ (57-4 to 57-7, Table 1, Fig. 2b). The analyses do not define a discórdia and lie close to but below an hypothetical line between $2712 \mathrm{Ma}$ and $2041 \mathrm{Ma}$, possibly due to recent lead loss which could not be eliminated by abrasion. The results are, however, compatible with this rock having undergone Transamazonian metamorphism that has partially reset the titanite. Zircons from the General Carneiro granite are very small, pervasively altered, and thus were not analyzed.

The Morro da Pedra granite (N-34) yielded very altered zircons of small size. A few pink and colorless zircon grains displayed a thick whitish cover; these were treated with HF and abraded as previously described. Two analyses were performed, one on the pink (analysis 34-1) and the other on the colorless type (34-2). Both analyses are discordant and yield minimum ages of $2682 \mathrm{Ma}$ and $2770 \mathrm{Ma}$ (Table 1, Fig. $2 \mathrm{c}$ ), the former being associated with a large error due to a high content of common $\mathrm{Pb}$. These results do not define the
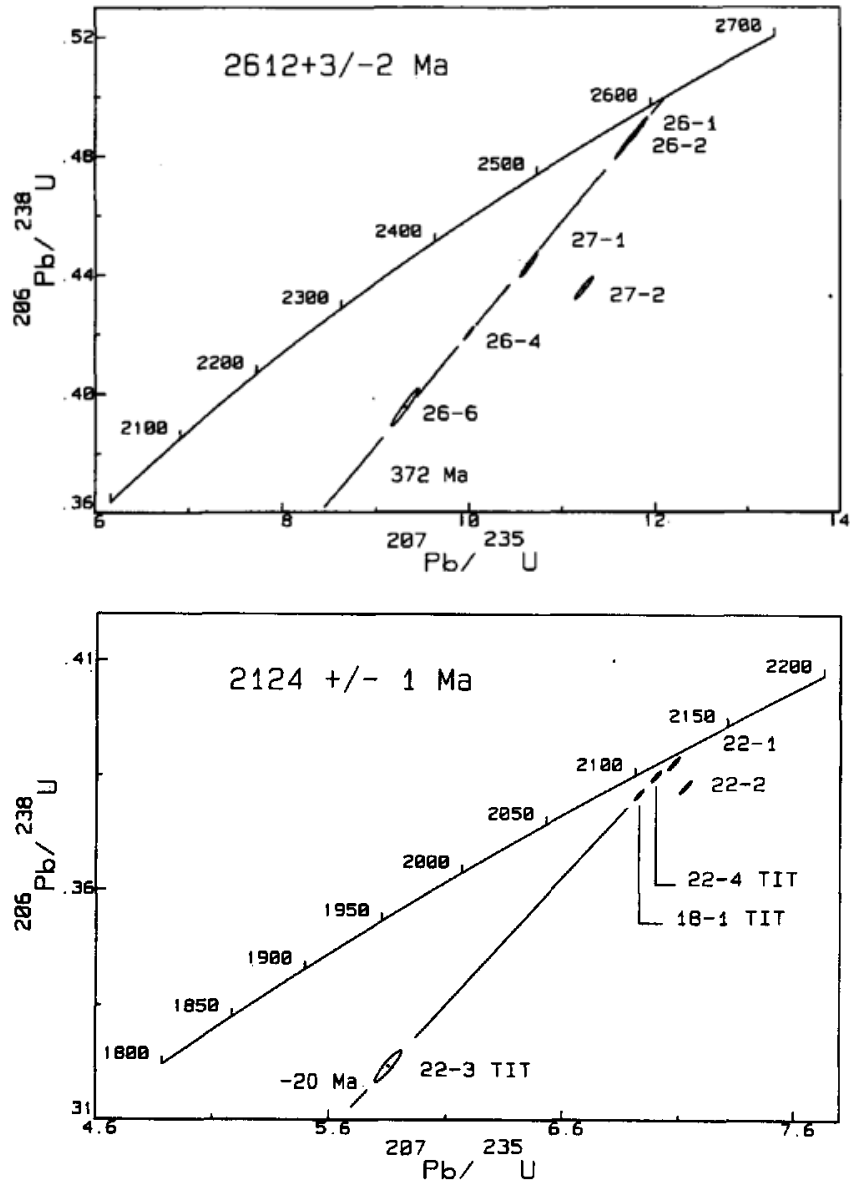

Figure 3 - (a) concórdia diagram for the Salto do Paraopeba granite (sample 26) and a pegmatite (sample 27). (b) concórdia diagram for the Alto Maranhão batholith (samples 18 and 22).

Figura 3 - (a) diagrama concórdia do granito Salto do Paraopeba (amostra 26) e um pegmatito (amostra 27). (b) diagrama concórdia do batólito Alto Maranhão (amostras 18 e 22). 
Table $1-U-P b$ results

\begin{tabular}{|c|c|c|c|c|c|c|c|c|c|c|c|c|c|c|c|c|c|}
\hline \multirow[b]{2}{*}{$\begin{array}{c}\text { Sample } \\
\text { no. }\end{array}$} & \multicolumn{3}{|c|}{ SAMPLE } & \multicolumn{3}{|c|}{ CONCENTRATIONS } & \multirow[b]{2}{*}{$\begin{array}{c}206 \mathrm{~Pb} \\
204 \mathrm{~Pb} \\
{[* n]}\end{array}$} & \multicolumn{6}{|c|}{ ATOMIC RATIOS } & \multirow[b]{2}{*}{ \pm} & \multicolumn{2}{|r|}{ AGES (Ma) } & \\
\hline & $\begin{array}{l}\text { Min. } \\
\text { ["] }\end{array}$ & "grains & $\begin{array}{c}\text { Weight } \\
\text { (mg) }\end{array}$ & $\begin{array}{c}\text { Uranium } \\
\text { (ppom) } \\
{[\text { [*] }}\end{array}$ & $\begin{array}{c}\text { Pb rad } \\
(\mathrm{ppm}) \\
{[\text { [I] }}\end{array}$ & $\begin{array}{c}\text { Pb comm. } \\
\text { (pg) } \\
\text { ["] }\end{array}$ & & $\begin{array}{c}208 \mathrm{~Pb} / \\
206 \mathrm{~Pb} \\
{[\cdots " \cdots]}\end{array}$ & 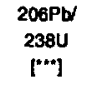 & \pm & $\begin{array}{c}207 \mathrm{~Pb} \\
235 \mathrm{U} \\
{[\cdots]}\end{array}$ & \pm & $\begin{array}{c}207 \mathrm{~Pb} / \\
206 \mathrm{~Pb} \\
{[\cdots]}\end{array}$ & & $206 \mathrm{~Pb} / 238 \mathrm{U}$ & $207 \mathrm{~Pb} / 235 \mathrm{U}$ & $07 \mathrm{~Pb} / 206 \mathrm{~Pb}$ \\
\hline \multicolumn{18}{|c|}{ Belo Horizonte Gneiss (Field numbers N-33A and N-33B) } \\
\hline 33B-1 & $z$ & 3 & 0,006 & 103 & 57 & 36 & 543 & 0.1251 & 0.48490 & 0,29 & 13,346 & 0,38 & 0,19962 & 0.200 & 2549 & 2704 & 2823 \\
\hline $33 \mathrm{~B}-2$ & $\mathbf{z}$ & 4 & 0.011 & 106 & 59 & 37 & 973 & 0,1435 & 0.48235 & 0,43 & 13,196 & 0.50 & 0,19842 & 0,300 & 2537 & 2694 & 2813 \\
\hline 338-3 & $\mathbf{z}$ & 15 & 0,009 & 164 & 108 & 70 & 761 & 0,1668 & 0,55922 & 0,87 & 15,747 & 0,93 & 0,20423 & 0,290 & 2863 & 2861 & 2860 \\
\hline $338-4$ & $\mathbf{z}$ & 1 & 0,005 & 75 & 47 & 41 & 331 & 0,0997 & 0,55713 & 0,24 & 16,303 & 0,26 & 0,21223 & 0,055 & 2855 & 2895 & 2923 \\
\hline 338-5 & $\mathrm{T}$ & 40 & 0,155 & 185 & 81 & 592 & 1139 & 0,2476 & 0,36878 & 0,14 & 6,399 & 0,16 & 0.12585 & 0,045 & 2024 & 2032 & 2041 \\
\hline 33A-1 & $T$ & 42 & 0.184 & 181 & 109 & 518 & 1660 & 0.5708 & 0,40688 & 0,33 & 8,249 & 0.34 & 0.14705 & 0.059 & 2201 & 2259 & 2312 \\
\hline $33 A-2$ & $T$ & 30 & 0.196 & 187 & 106 & 751 & 1233 & 0,5125 & 0,39757 & 0.25 & 7,674 & 0,26 & 0,13999 & 0,075 & 2158 & 2194 & 2227 \\
\hline \multicolumn{18}{|c|}{ Santa Luzia Granite (Field number N-57) } \\
\hline $57 \cdot 1$ & $\mathbf{z}$ & 8 & 0,010 & 167 & 94 & 61 & 785 & 0,263 & 0,45131 & 0,15 & 11,325 & 0,25 & 0,18199 & 0.061 & 2401 & 2550 & 2671 \\
\hline $57-2$ & $\mathbf{z}$ & 16 & 0.019 & 84 & 49 & $\theta$ & 8570 & 0.2322 & 0,48288 & 0.14 & 12,264 & 0.15 & 0.18420 & 0,045 & 2540 & 2625 & 2691 \\
\hline $57-3$ & $z$ & 13 & 0,015 & 85 & 49 & to & 3831 & 0.221 & 0,47578 & 0,14 & 12,046 & 0,15 & 0,18363 & 0,043 & 2509 & 2608 & 2686 \\
\hline $57-4$ & $\mathbf{T}$ & 50 & 0,536 & 103 & 67 & 2193 & 631 & 0,8079 & 0,36932 & 0,20 & 7,449 & 0,47 & 0,13878 & 0,370 & 2120 & 2167 & 2212 \\
\hline $57-5$ & $\mathbf{T}$ & 30 & 0,346 & 141 & 97 & 1824 & 671 & 0,8369 & 0,40099 & 0.43 & 7,985 & 0,50 & 0,14443 & 0,100 & 2174 & 2229 & 2281 \\
\hline $57-6$ & $\mathbf{T}$ & 15 & 0.204 & 151 & 108 & 1351 & 600 & 0.8683 & 0,40903 & 0.43 & 8,373 & 0,50 & 0.14847 & 0,100 & 2210 & 2272 & 2328 \\
\hline 57.7 & $\mathbf{T}$ & 20 & 0.254 & 162 & 111 & 1939 & 558 & 0,7945 & 0,40744 & 0,45 & 8, 158 & 0,50 & 0,14522 & 0,100 & 2203 & 2249 & 2290 \\
\hline \multicolumn{18}{|c|}{ Morro da Pedra Granilie (Field number N-34) } \\
\hline 34-1 & $\mathbf{z}$ & 2 & 0,007 & 130 & 82 & 303 & 108 & 0,2722 & 0,4995 & 0,53 & 12.617 & 0.77 & 0.18320 & 0,670 & 2612 & 2651 & 2682 \\
\hline $34-2$ & $z$ & 5 & 0,007 & 143 & 85 & 104 & 307 & 0,2325 & 0,4837 & 0,41 & 12,889 & 0.50 & 0.19325 & 0,200 & 2544 & 2672 & 2770 \\
\hline \multicolumn{18}{|c|}{ Córrego do Brumado Granite (Field number N-04) } \\
\hline $4-1$ & $\mathbf{M}$ & 4 & 0,009 & 3241 & 7489 & 763 & 888 & 6,2167 & 0,36331 & 0.14 & 6.319 & 0,20 & 0.12614 & 0.093 & 1998 & 2021 & 2045 \\
\hline \multicolumn{18}{|c|}{ Salto do Paraopeba Granite (Fisld number N-26) } \\
\hline $26-1$ & $\mathbf{z}$ & 1 & $<0.001$ & 347 & 199 & 37 & 300 & 0,1916 & 0,4887 & 0,42 & 11,813 & 0,44 & 0,17531 & 0,080 & 2565 & 2590 & 2609 \\
\hline $26-2$ & $\mathbf{z}$ & 1 & $<0.001$ & 268 & 150 & 11 & 773 & 0,1717 & 0,4837 & 0,50 & 11,679 & 0,50 & 0.17511 & 0,067 & 2543 & 2579 & 2607 \\
\hline $26-4$ & $\mathbf{z}$ & 1 & 0,003 & 215 & 101 & 22 & 799 & 0.1267 & 0.4202 & 0,24 & 9,998 & 0,26 & 0.17256 & 0.055 & 2261 & 2435 & 2583 \\
\hline $26-6$ & $\mathbf{z}$ & 1 & $<0.001$ & 183 & 86 & 33 & 153 & 0,2051 & 0,3954 & 0.76 & 9.311 & 0.79 & 0.17080 & 0.177 & 2148 & 2369 & 2566 \\
\hline \multicolumn{18}{|c|}{ Salto do Paraopeba Pegmatite (Field number N-27) } \\
\hline $27-1$ & $\mathbf{z}$ & 2 & $<0.001$ & 386 & 201 & 53 & 218 & 0,1883 & 0,4431 & 0,40 & 10.637 & 0.43 & 0.17409 & 0.110 & 2365 & 2492 & 2597 \\
\hline $27-2$ & $\mathbf{z}$ & 7 & 0,002 & 255 & 130 & 34 & 430 & 0.1761 & 0.4354 & 0.40 & 11,231 & 0,43 & 0.21400 & 0,115 & 2330 & 2543 & 2677 \\
\hline \multicolumn{18}{|c|}{ Atto Maranhăo Batholith (Field numbers N-22 and N-18) } \\
\hline $22-1$ & $\mathbf{z}$ & 3 & 0,004 & 371 & 157 & 13 & 2768 & 0,1326 & 0,38779 & 0.17 & 7,078 & 0,18 & 0,13237 & 0.052 & 2113 & 2121 & 2130 \\
\hline $22-2$ & $z$ & 20 & 0,014 & 139 & 57 & 13 & 3663 & 0,1127 & 0,38256 & 0.17 & 7,129 & 0,18 & 0.13516 & 0,054 & 2088 & 2128 & 2166 \\
\hline $22-3$ & $\mathbf{T}$ & 55 & 0,217 & 156 & 52 & 4504 & 165 & 0.0996 & 0.31717 & 0,45 & 5,775 & 0,50 & 0.13205 & 0.200 & 1776 & 1943 & 2125 \\
\hline 22.4 & $\mathbf{T}$ & 40 & 0,162 & 75 & 29 & 784 & 391 & 0,0236 & 0,38493 & 0,13 & 7,001 & 0.15 & 0,13192 & 0,059 & 2099 & 2112 & 2124 \\
\hline 18 & $T$ & 40 & 0.188 & 201 & 92 & 561 & 1623 & 0,2722 & 0,38083 & 0,13 & 6,927 & 0,15 & 0,13192 & 0,044 & 2080 & 2102 & 2124 \\
\hline
\end{tabular}

Notes:

-Z-zircon; T- titanite; M-monazile.

*- Concentrations are known to $2 \%$ for sample weights of $0.4 \mathrm{mg}, 10 \%-20 \%$ for sample weights below $0.020 \mathrm{mg}$ (for sample weights below the sensitivity of the microbalance, shown as $<0.001$.

the concentrations listed are maximum values

*- Total common Pb present corrected lor Pb in spike.

*i: - Measured ratio, corrected for tractionation only.

... - Ratios corrected for spike, fractionation, blank and initial common Pb. Precision is reported in \% at 1 sigma

age of the rock and are tentatively interpreted as minimum ages of zircon inheritance.

The Córrego do Brumado granite (N-4) also contains zircons that are unsuitable for geochronological analyses. Monazite yielded a ${ }^{207} \mathrm{~Pb} /{ }^{206} \mathrm{~Pb}$ age of $2045 \mathrm{Ma}$ (2.3\% discordant, Table 1, Fig. 2c) which is taken as the minimum crystallization age for the granite.

The slight deformation present in the Morro da Pedra and Córrego do Brumado granites, together with the similarity of their chemical compositions, suggest that they may be approximately coeval. If this is the case, they were emplaced during the peak of Transamazonian metamorphism.

SOUTHERN QUADRILÁTERO FERRÍFERO The Salto do Paraopeba granite (N-26) yielded flattened 3:1 zircon crystals, fractured across their length suggesting the absence of cores. Two prisms were broken, abraded and the four fragments analyzed separately. The analyses are 3-19\% discordant and define a discórdia ( $87 \%$ probability of fit) with an upper intercept at 2612+3/-2 Ma (Table 1, Fig. 3a), taken as the age of crystallization of the granite.

The pegmatites (N-27) intruded into the quartzites of the Minas Supergroup contain a very small amount of heavy minerals. Analysis 27-1 was performed on two small pink euhedral fragments and analysis $27-2$ on seven similar grains from a more magnetic fraction. The analyses are $11 \%$ and $14 \%$ discordant and yield ${ }^{207} \mathrm{~Pb} /{ }^{206} \mathrm{~Pb}$ ages of $2597 \mathrm{Ma}$ and 2677 Ma (Table 1, Fig. 3a). Analysis 27-1 plots on the discórdia defined for the Salto do Paraopeba granite and may suggest that the pegmatite is coeval with the granite. However, analysis 27-2 clearly indicates the presence of inherited zircons in the pegmatite and it is not possible to decide if $27-1$ also represents inherited zircon. Therefore, it can only be stated that the maximum age for the crystallization of the pegmatite is probably $2612 \mathrm{Ma}$.

Zircons from the Alto Maranhão pluton (N-22, N-18) are pink, euhedral and devoid of visible cores. Two analyses yield minimum ages of $2130 \mathrm{Ma}$ and $2166 \mathrm{Ma}$ (analyses 22-1 and $22-2,0.8 \%$ and $4 \%$ discordant, respectively) indicating the 


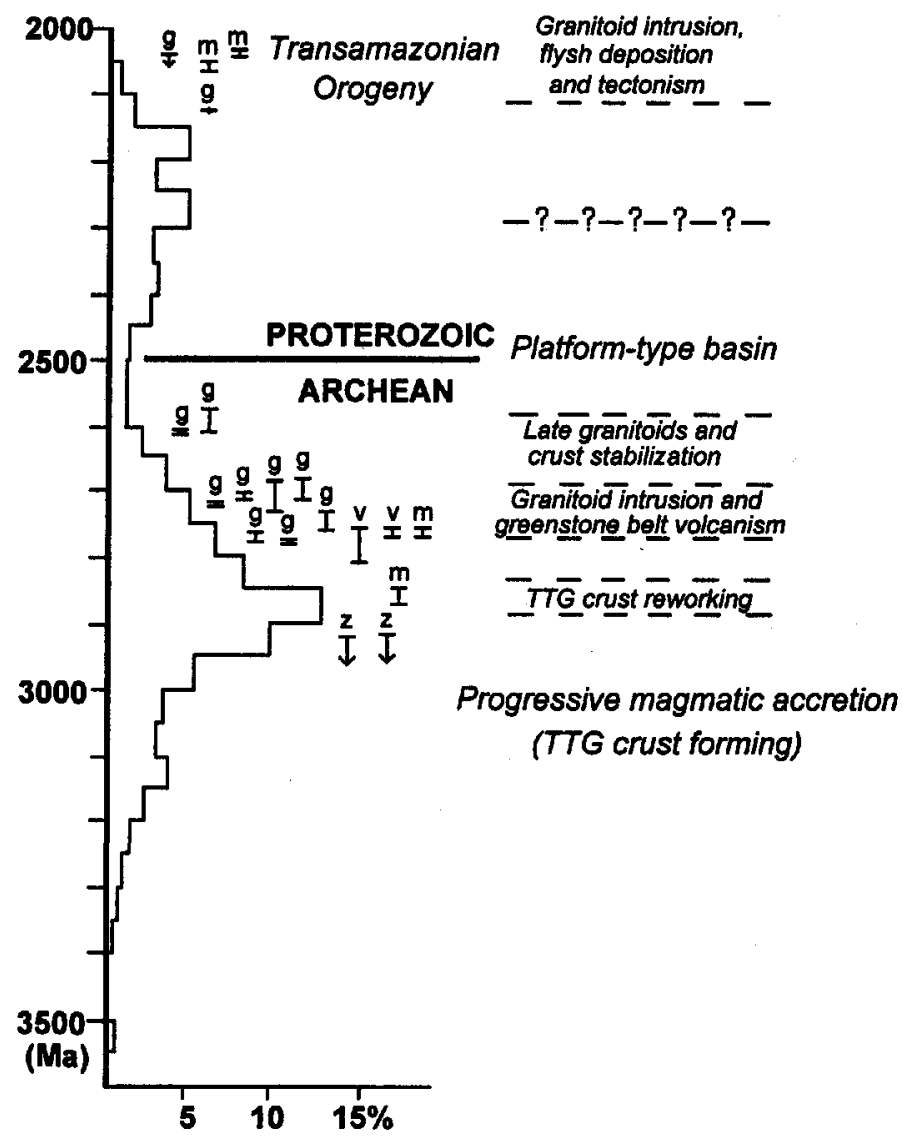

Figure $4 \cdot$ Summary of the U-Pb ages for the Quadrilatero Ferrifero and the main events they represent $(U-P b$ ages from Romano et al. 1991, Machado et al. 1992, Machado \& Carneiro 1992, Chemale et al. 1993). The histogram to the left represents detrital zircon age distribution, amounting to 449 zircons from Archaean and Proterozoic clastic units of the Quadrilátero Ferrifero (after Machado et al. 1996b). Legend: g. granitoid pluton, v. volcanic rock, in. metamorphic age, z. minimum age of inherited zircon. Figura 4 - Resumo das idades U-Pb do Quiadrilátero Ferrífero e os principais eventos que representam (idades U-Pb obtidas por Romano et al. 1991, Machado et al. 1992, Machado \& Carneiro 1992, Chemale et al. 1993). O histograma da esquerda representa a distribuição de idades de zircão detrítico, totalizando 449 zircões de unidades elásticas arqueanas e proterozóicas do Quadrilátero Ferrífero (seg. Machado et al. 1996b). Legenda: g. plútons de granitóioides, v. rochas vulcânicas, m.idade do metamorfismo, z. idade mínima de zircão herdado.

presence of inheritance in the tonalite. Two titanite fractions yield identical ${ }^{207} \mathrm{~Pb} /{ }^{206} \mathrm{~Pb}$ ages of $2125 \mathrm{Ma}$ and $2124 \mathrm{Ma}$ (22-3 and $22-4,1.4 \%$ and $19 \%$ discordant). One titanite fraction analysis from another sample (N-18) is $2.4 \%$ discordant and yields an identical ${ }^{207} \mathrm{~Pb} /{ }^{206} \mathrm{~Pb}$ age of $2124 \mathrm{Ma}$. The three titanite analyses define a discórdia ( $97 \%$ probability of fit) with an upper intercept age of 2124 \pm 1 Ma (Table 1, Fig 3b) taken as the age of crystallization of the pluton.

Sample N-18 yields a Nd model age (TDM) of $2.2 \mathrm{Ga}$ (Noce 1995), similar to the age of crystallization, and a positive $£ \mathrm{Nd}$ value of +1.1 suggesting that the tonalitic magma could be largely mantle derived. However, the presence of inherited zircon indicates a small degree of crustal assimilation by the magma.
GEOLOGICAL IMPLICATIONS AND CONCLUSIONS A summary of U-Pb data for the Quadrilatero Ferrífero is shown in figure 4, where magmatic and metamorphic episodes are compared to a detrital zircon age histogram. The histogram is based on more than 400 detrital zircons from clastic units of the Rio das Velhas greenstone belt, Minas Supergroup and Itacolomi Group, and ages were obtained by Laser-ablation-ICPMS and isotope dilution (Machado et aí. 1996b). The presence of 3.5-3.0 Ga continental crust in the Quadrilátero Ferrífero is only suggested by detrital zircon dating. The age distribution of detrital zircon increases after $3.0 \mathrm{Ga}$, probably reflecting an increase in crust-growth processes. The peak at 2900-2850 Ma coincides with geological events recorded in the Belo Horizonte, Campo Belo and Gouveia complexes (Machado et al. 1989, Teixeira et al. 1998). This tectonothermal event probably affected the entire pre-existing continental crust in a manner similar to that proposed by Choukroune et al. (1995).

The migmatization event at $2860+14 /-10 \mathrm{Ma}$ in the Belo Horizonte complex affected a TTG-type gneiss which protholith is at least $2922 \mathrm{Ma}$ and probably not older than 3.0 Ga. During this event, the gneiss was strongly deformed and developed the regional N-S low angle foliation also found in the northern sector of the Bonfim complex (Carneiro 1992) and, more generally, to the west of the Quadrilátero Ferrífero.

Archaean events after 2860 Ma were episodic, short-lived, and could be related to a progressive accretion of crustal blocks reaching final cratonization at $c a$. $2600 \mathrm{Ma}$. The bestcharacterized event in the Quadrilátero Ferrífero took place in the 2780-2700 Ma time interval. Felsic volcanism dated at 2776-2772 Ma was coeval with granitoid emplacement at 2780-2776 Ma in the northern (Caeté granodiorite) and western (Samambaia tonalites) margins of the greenstone belt (Machado et al. 1992, Machado \& Carneiro 1992). Less extensive and crust-derived granitoids occurring in the Belo Horizonte and Bonfim complexes represents further magmatic activity. In the former, foliated granitoids were dated at 2712+5/-4 Ma (the Santa Luzia and possibly the General Carneiro granite) and at $2698 \pm 18 \mathrm{Ma}$ (U-Pb age of Ibirité granodiorite; Chemale et al. 1993). In the Bonfim complex, the Mamona granodiorite was dated at $2721 \pm 3 \mathrm{Ma}$ (Machado et al. 1992), and the Brumadinho granite at 2703+24/-20 Ma (Machado \& Carneiro 1992).

The youngest Archaean granitoids found in the Quadrilátero Ferrífero area are the Salto do Paraopeba granite $(2612+3 /-2 \mathrm{Ma})$ and the Caio Martins granite (259318 Ma, Romano et al. 1991).

Other Archaean cratons such as the Yilgarn of Western Australia, the Superior Province of Canada and the Kaapvaal and Zimbabwe cratons of southern Africa show similar kinds of broadly contemporaneous events at 2.8-2.6 Ga, which may reflect the formation of a supercontinent, or supercontinents, at this time (Myers 1995). Different tectonic environments have been proposed for Neoarchean greenstone belt formation and final cratonization. In the Superior Province, greenstone belts like the Abitibi evolved largely in an oceanic environment (Corfu 1993) and island-arc accretion played a major role in continental growth (Card 1990). In the Quadrilátero Ferrífero, older continental crust was a major source for greenstone belt sediments (Machado et al. 1996b), and cratonization was probably accomplished by amalgamation of a number of microcontinents.

Cratonic conditions and the absence of magmatic activity prevailed in the 2.6-2.4 time interval (see Fig. 4). The lower succession of the Minas Supergroup, consisting of fluvial sandstones and stable-shelf pelites, iron formation, ferruginous dolomites and dolomites, represents an Archaean-Paleoproterozoic cratonic cover. Its maximum age is defined by the emplacement of ca. 2600 Ma granitic plutons (e.g. Salto do 
Paraopeba granite) while dolomitic rocks overlying the Cauê Iron Formation yielded a $\mathrm{Pb}-\mathrm{Pb}$ whole-rock isochron of $2420 \pm 19$ Ma (Babinski el al 1995). The Transvaal Supergroup in the Kaapvaal craton, and the Hamersley Group in the margins of the Pilbara craton, are similar to the lower Minas Supergroup. Both units are broadly time equivalent and were deposited after $2.68 \mathrm{Ga}$ (Cheney 1996, Sumner \& Bowring 1996). Their minimum age is not well constrained, but reported $\mathrm{U}-\mathrm{Pb}$ ages for the Brockman Iron Formation (Hamersley Group) and the Griquatown Iron Formation (Transvaal Supergroup) are, respectively, 2470 \pm 4 Ma and $2432 \pm 31 \mathrm{Ma}$ (Cheney 1996).

Source rocks for 2.4-2.2 Ga detrital zircons (Fig. 4) have not been found in the Quadrilátero Ferrífero and geologic events at this period remain highly speculative. A collisional belt developed at the margins of the former Archaean platform after 2.2 Ga. The flysch-like sediments of the Sahara Formation clearly mark a complete change both in depositional environment and source of sediments from those represented in the older units of the Minas Supergroup (Dorr 1969). The striking coincidence between the $2125 \pm 4$ Ma age for the youngest zircon found in the Sahara Formation (Machado et ai. 1992) and the 2124 \pm 1 Ma age of the Alto Maranhão pluton indicates that the flysch sedimentation and the igneous activity during the Transamazonian Orogeny are contemporaneous.

Transamazonian metamorphism is recorded in the Belo Horizonte gneiss by titanite ages of $2041+5 \mathrm{Ma}$ and by the emplacement of granitic stocks at $c a$. $2045 \mathrm{Ma}$, in agreement with titanite and monazite ages of 2060-2030 Ma for amphibolite and pegmatite in the Bação Complex (Machado et al. 1992).

$\mathrm{Rb}$-Sr whole-rock ages and $\mathrm{K}-\mathrm{Ar}$ mineral ages are remarkably incoherent in the Quadrilátero Ferrífero. For example, samples of the Alto Maranhão pluton from the same locations sampled for $\mathrm{U}-\mathrm{Pb}$ analyses $(2124 \pm 1 \mathrm{Ma})$ yielded $\mathrm{K}-\mathrm{Ar}$ biotite ages of $1000 \pm 22 \mathrm{Ma}$ and $730 \pm 25 \mathrm{Ma}$ and $\mathrm{Rb}$-Sr whole-rock ages of $664 \pm 80$ and $484 \pm 37 \mathrm{Ma}$ (Noce 1995). Isotopic disturbance of $\mathrm{Sr}$ and Ar systems must be related to post-Transamazoniam events, especially the Braziliano Orogeny (ca. 600 $\mathrm{Ma}$ ). This event probably played a minor role in the structural evolution of the Quadrilátero Ferrífero, inducing the reactivation of former structures especially in the eastern part of the area.

Acknowledgments Field and laboratory work in Brazil were supported by FAPEMIG (Minas Gerais) and FAPESP (Sao Paulo). The personnel of CPGeo (São Paulo) and CPMTC (Universidade Federal de Minas Gerais) are thanked for technical support. F. Robert and R. Lapointe are thanked for sustained technical support and Michelle Laithier for map drawing. The UQAM geochronology laboratory is supported by infrastructure grants from NSERC (Canada) and FCAR (Quebec). N.M. acknowledges support from NSERC (Canada).

\section{REFERENCES}

Babinski, M.; Chemale, F.; Van Schumus, W.R. 1995. The $\mathrm{Pb} / \mathrm{Pb}$ age of the Minas Supergroup carbonate rocks, Quadrilátero Ferrífero, Brazil. Precambrian Research, 72:235-245

Card, K.D. 1990. A review of the Superior Province of the Canadian Shield, a product of Archean accretion. Precambrian Research, 48:99-156

Carneiro, M.A. 1992. O Complexo Metamórfico Bonfim Setentrional (Quadrilátero Ferrifero, Minas Gerais): Litoestratigrafia e evolução geológica de um segmento de crosta continental do Arqueano. Inst. de Geociências, Universidade de São Paulo, São Paulo, Tese de Doutoramento, $233 \mathrm{p}$.

Chapell, B.W.; White, A.J.R. 1974. Two contrasting types of granites. Pacific Geology, 8:113-114

Chemale., P.; Babinski, M.; Van Schumus, W.R. 1993. U/Pb dating of granitic-gneissic rocks from the Belo Horizonte and Bonfim complexes, Quadrilátero Ferrífero (Brazil): Report for $\mathrm{CNPq}$ and NSF-EAR Project on São Francisco Craton Margin Transect Project, 16 p. (unpubl.).

Cheney, E.S. 1996. Sequence stratigraphy and plate tectonics significance of the Transvaal succession of southern Africa and its equivalent in Western Australia. Precambrian Research, 79:3-24

Choukroune, P.; Bouhallier, H.; Arndt, N.T. 1995. Soft lithosphere during periods of Archaean crustal growth or crustal reworking. In M.P. Coward \& A.C. Ries (eds.) Early Precambrian Processes. London, Geological Society Special Publication, n. 95,67-86

Corfu, F. 1993. The evolution of the southern Abitibi greenstone belt in light of precise U-Pb geochronology. Economic Geology, 88:1323-1340

Davis, D.W. 1982. Optimum linear regression and error estimation applied to U-Pb data. Canadian Journal of Earth Sciences, 19:2141 -2149

Dorr II, J.V.N. 1969. Phisiographic, stratigraphic and structural development of the Quadrilátero Ferrífero, Minas Gerais, Brazil. U.S. Geological Survey Professional Paper, 641-A: I -110

Dorr II, J.V.N.; Gair, J.E.; Pomerene, J.G.; Rynearson, G.A. 1957. Revisão da estratigrafia pré-cambriana do Quadrilátero Ferrífero. Rio de Janeiro, DNPM-DFPM, 31 p. (Avulso 81)

Herz, N. 1970. Gneissic and igneous rocks of the Quadrilátero Ferrífero, Minas Gerais, Brazil. U.S. Geological Survey Professional Paper, 641-8:1-58

Krogh, T.E. 1973. A low contamination method for hydrothermal decomposition of zircon and extraction of $\mathrm{U}$ and $\mathrm{Pb}$ for isotopic age determination. Geochimica et Cosmochimica Acia, 37:488-494
Krogh, T.E. 1982. Improved accuracy of U-Pb zircon ages by the creation of more concordant systems using an air abrasion technique. Geochimica et Cosmochimica Ada, 46:637-649

Machado, N.; Schrank, A.; ABREU, F.R.; KNAUER, L.G.; ALMEIDA-ABREU, P.A. 1989. Resultados preliminares da geocronologia $\mathrm{U}-\mathrm{Pb}$ na Serra do Espinhaço Meridional. In: SBG/Núcleo Minas Gerais, Simp. Geol. de Minas Gerais, 5, Belo Horizonte, Anais, 1 -4

Machado, N.;Carneiro, M.A. 1992. U-Pb evidence of late Archean tectono-thermal activity in the southern São Francisco shield, Brazil. Canadian Journal of Earth Sciences, 29:2341-2346

Machado, N.; Noce, C.M.; Ladeira, E.A.; Belo de Oliveira, O.A. 1992. U-Pb geochronology of Archean magmatism and Proterozoic metamorphism in the Quadrilátero Ferrífero, southern São Francisco Craton, Brazil. Geological Society of America Bulletin, 104:1221 -1227

Machado, N.; Valladares, C.; Heilbron, M.; Valeriano, C. 1996a. U-Pb geochronology of the central Ribeira Belt (Brazil) and implications for the evolution of the Brazilian Orogeny. Precambrian Research, 79:347-361

Machado, N.; Schrank, A.; Noce, C.M.; Gauthier, G. 1996b. Ages of detrital zircon from Archean-Paleoproterozoic sequences: Implications for Greenstone Belt setting and evolution of a Transamazonian foreland basin in Quadrilátero Ferrífero, southeast Brazil. Earth and Planetary Science Letters, 141:259-276

Myers, J.S. 1995. The generation and asembly of an Archaean supercontinent: evidence from the Yilgarn craton, Western Australia. In M.P. Coward \& A.C. Ries (eds.) Early Precambrian Processes. London, Geological Society Special Publication, n. 95, p. 143-154.

Noce, C.M. 1995. Geocronologia dos eventos magmáticos, sedimentares e metamórficos na região do Quadrilátero Ferrifero, Minas Gerais. Inst. de Geociências, Universidade de São Paulo, São Paulo, Tese de Doutoramento, $129 \mathrm{p}$.

Noce, C.M.; Teixeira, W.; Machado, N. 1997. Geoquímica dos gnaisses TTG e granitóides neoarqueanos do Complexo Belo Horizonte, Quadrilátero Ferrífero, Minas Gerais. Revista Brasileira de Geociências, 27:25-32

Pomerene, J.B. 1964. Geology of Belo Horizonte, Ibirité and Macacos quadrangles. U.S. Geological Survey Professional Paper, 341-D:1-84 
Romano, A.W.; Bertram!, J.M.; Michard, A.; Zimmermann, J.L. 1991. Tectonique tangentielle et décrochements d'age Protérozoique inféríeur (orogenèse transamazonienne, environ $2000 \mathrm{Ma}$ ) au Nord du "Quadrilátero ferriíere" (Minas Gerais, Brésil): Complex Rendus de l'Academic dês Sciences de Paris, 313:1195-1200

Sad, J.H.G.; Pinto, C.P.; Duarte, C.L. 1983. Geologia do distrito manganesífero de Conselheiro Lafaiete, MG. In: SBG/Núcleo Minas Gerais, Simp. Geol. de Minas Gerais, 2, Belo Horizonte, Amiix, 259-270

Stacey, J.S.; Kramers, J.D. 1975. Approximation of terrestrial lead isotope evolution by a two-stage model. Earth and Planetary Science Letters, 26:207-221
Sumner, D.Y. Bowring, S.A. 1996. U-Pb geochronologic constraints on deposition of the Campbellrand Subgroup, Transvaal Supergroup, South Africa. Precambrian Research, 79:25-35

Teixeira, W.; Cordani, U.G.; Nutman, A.; Sato, K. 1998. Polyphase Archean evolution in the Campo Belo metamorphic complex, Southern São Francisco, Brazil: SHRIMP U-Pb zircon evidence. Journal of South American Earth Sciences (in press).

Manuscrito A-954

Recebido em 28 de janeiro de 1998

Revisão dos autores em 14 de abril de 1998-05-03

Revisão aceita em 15 de abril de 1998 